International Journal of Engineering \& Technology, $7(2.23)(2018) 216-220$
International Journal of Engineering \& Technology
SPC
Website: www.sciencepubco.com/index.php/IJET
Research paper

\title{
Estimation of occupational safety risks at energetic sector of Iron and Steel Works
}

\author{
Volodymyr Kukhar $^{1 *}$, Nelly Yelistratova ${ }^{2}$, Vadym Burko $^{3}$, Yulia Nizhelska ${ }^{4}$, Olga Aksionova ${ }^{5}$ \\ ${ }^{1}$ Department of Metalforming, Pryazovskyi State Technical University, Mariupol, Ukraine \\ ${ }^{2}$ Department of Occupational Safety and Environmental Engineering, Pryazovskyi State Technical University, Mariupol, Ukraine \\ ${ }^{3}$ Department of Occupational Safety and Environmental Engineering, Pryazovskyi State Technical University, Mariupol, Ukraine \\ ${ }^{4}$ Department of Occupational Safety and Environmental Engineering, Pryazovskyi State Technical University, Mariupol, Ukraine \\ ${ }^{5}$ Department of Occupational Safety and Environmental Engineering, Pryazovskyi State Technical University, Mariupol, Ukraine \\ *Corresponding author E-mail: kvv.mariupol@gmail.com
}

\begin{abstract}
Modern methods of estimation of working conditions at the metallurgical enterprise are considered on the occupational safety due to European standards. The main approaches are identified in determination of hazards at work, assessing of technological risks and injuries as an example for one of the Iron and Steel Works, Mariupol, Ukraine. The purpose of this work is to analyze the effectiveness of the introduction of international methods in the field of health safety, assess the effectiveness of the safety management system at an industrial enterprise. The analysis of the process of implementing European standards in the field of the health safety at industrial enterprises is a prerequisite for their further successful application, reducing the level of injuries. The procedures for drawing up the matrix of risk assessment (HAZID method), assessment of working capacity of technological processes (HAZOP method), and safety assessment of works (ISA method) are considered. The analysis of the efficiency of measures to increase of health safety in the energy (gas) sector at the enterprise was carried out. A graph of the dynamics of the decline in industrial injuries in five years is shown. The main statistical indicators that are used to account for industrial injuries at an industrial enterprise are given.
\end{abstract}

Keywords: Industrial Injuries; Occupational Safety Studies; Technology Risk Assessment; Accident; International Standards.

\section{Introduction}

Industrial enterprises of Ukraine, which adopt the European vector of development, set themselves the task of increasing the effectiveness of the Occupational Safety Management System and Health Safety. Effective schemes to improve the occupational safety are fulfilled through the implementation of an Occupational Health and Safety Assessment Series OHSAS 18000, which combines two standards [1, 2]: OHSAS 18001:2007 "Occupational Health and Safety Management System. Requirements", and OHSAS 18002:2008 "Occupational health and safety management systems. Guidelines for the implementation of OHSAS 18001:2007". The strategy is to improve the occupational safety, reduce injuries and professional diseases of workers, achieved by the introduction of European Union directives [3 - 8] and international standards [9-12], as well as approaches based on the best domestic practices [13-16]. The process is established by regulatory documents in the field of risk management, containing methodological recommendations on the procedure of risk analysis on the workplace. There rules for attesting workplaces for the working conditions, identifying sources of danger, qualitative and quantitative risk assessment, criteria for their acceptable level are in this list.

The analysis of the process of European standards implementation in the field of occupational safety at the enterprises of Ukraine is necessary for their further successful application, reducing the level of industrial injuries.
Modern scientific and methodological approaches of the managing risks in the system of occupational safety include the following stages: identification of technological problems and problem situations; identification the sources of risks in the field of occupational safety; development of options for eliminating risks or bringing them to the acceptable value; optimal solution of the problem by the criteria of effectiveness, optimality, efficiency [2, 5, $8-11]$. This methodology corresponds to the order of risk assessment, and the practical approach is based on the international standards ISO 31000:2015 "Risk management - A practical guide for SMEs" (Figure 1) and ISO 31000:2009 "Risk management - Principles and guidelines".

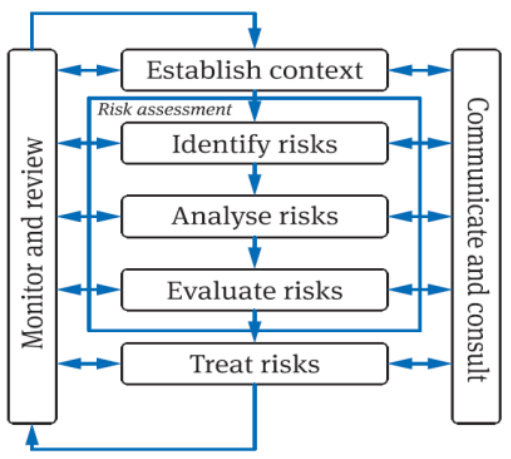

Fig. 1: The ISO 31000:2009 risk management process 
The designation of its harmonized normative standard is ISO 73.2003. The document defines the main terms and concepts in the field of occupational safety.

The principles of the industrial risks are covered in the standard IEC 61882:2016 "Hazard and operability studies (HAZOP studies) - Application guide", with outlining practical recommendations for assessment and accounting using the HAZOP (Hazard Operability) methodology. It contains a procedure of describing the potential hazards of technological systems, as well as their operability and the causes of operational violations. The document has been widely applied and regulates the key stages of quantitative and qualitative risk according to the international methods HAZID (Hazard Identification), determining the scenarios for their development Bow-Tie (Bow-Tie Model), methods for regulating the safe work JSA (Job Safety Analysis), and also identification of the industry impact on the environment using the method ENVID (Environment Impact Identification).

At the present, the HAZID method is used at the stages of design development, planning of various types of industrial activities and reporting procedures of Occupational Safety (OS), Industrial Safety (IS), Environmental Protection (EP); in preparation of a particular type of works [2, 3, 6, 7, 14]. An important advantage of this method is its ability to establish and demonstrate the link between the risks of OS, IS, EP, and risk management activities. Which determine through the analysis of the hazards and risks, based on the description of the process, the process flow diagram, the results of previous risk assessments, the risk register and accident investigation reports $[1,2,10]$.

The JSA method - a work safety survey is used to assess and manage the risks of IS, EP, which occur when staffing and nonstaff activities are performed to serious consequences [6 - 11]. Risk assessment is an ongoing and systematic process, carried out in stages, taking into account previously identified hazards. Thus, a unified approach at the enterprises is formed to increase occupational safety on the workplaces and determine environmental damage [6-11, $14-16]$.

At the same time, there assess of the state and operating modes of the equipment $[17-19]$, of the stress-strain state of the treated workpieces [20 - 23] to exclude their destruction and injuries to people is necessary to estimation of the personnel safety at the working conditions in production workshops. Risk assessment methods have been implemented in different countries and in different industries [24 - 32]. However, for the conditions of the metallurgical enterprises of Ukraine, the reduction of occupational injuries requires the introduction of organizational and technical measures, the improvement of the methodology for risk assessment and has not been sufficiently studied to date.

The purpose of this work is to analyze the effectiveness of the introduction international methods of risk estimation in the field of occupational safety, the potency of the safety and health management system, using the example of the of the PJSC "AZOVSTAL" Iron and Steel Works (Mariupol, Ukraine).

\section{Methodology}

At the present day, several methods of assessing work conditions at workplaces and procedures for determining industrial risks are used at the industrial enterprises of Ukraine. They are divided into: expert methods for auditing the risks of the industrial process; methods with application of risk scenarios analysis and conclusions of industry experts; methods of statistical analysis of accidents or diseases. The first of them received practical use only in recent years.

Thus, the METINVEST Group (a vertically integrated group of steel and mining companies, including the PJSC "AZOVSTAL" Iron and Steel Works) since 2012 has embarked on the implementation of a technological risk management system, developing "Normative and methodological recommendations for identifying of hazards and assessing of production risks in the field of health safety engineering, occupational safety and environmental engi- neering". This document is based on four international methods: HAZID - Hazard Identification of Occupational Safety; HAZOP Hazard and Operability Study; ENVID - Environmental Impact Identification; JSA - A Job Safety Analysis. To carry out the procedure for assessing industrial risks was created a working group (WG) of internal experts - specialists in in the field of health safety engineering, occupational safety and environmental engineering with the participation of industrial managers, engineers of technology, and specialists of technique service.

When working according to the HAZID method, experts divide the technological processes or objects into elements and analyze all inherent dangerous and harmful factors. In this regard a "List of specific hazards" was compiled with the assignment of an individual number to each technological element. For example, the area of hazards in the energetic sector includes the entire range of explosive and fire hazardous and poisonous substances: hydrocarbons (H-01), refined hydrocarbons (H-02), other flammable materials $(\mathrm{H}-03)$, explosives $(\mathrm{H}-04)$, sources hazards that can cause suffocation (H-18), toxic gases and liquids. The list includes objects using: increased pressure, equipment under induced stress, hot surfaces and liquids, refrigerants. Ergonomic hazards are also taken into account (H 05-020).

At the second stage, with the help of the "Risk assessment Matrix of health safety engineering, occupational safety and environmental engineering" (Table 1 and Table 2), for each element, the "Current Risk Level" is established for the three-tier system. The first level of industrial risk is indicated by the color: high - "red", medium - "yellow", low - "green". The second level is a numerical value (from 1 to 5), depending on the severity of the actual or potential consequences. The third level is the score in points (from 1 to 5 ), determined by the probability of occurrence of the predicted consequences. At its values of less than $5 \%$, the level is one point, with more than $60 \%$ - five ones.

The matrix includes analysis by sections: "Humans", "Environment", "Assets", "Reputation". After evaluations are completed, a HAZID table is created for a specific area of the workshop or equipment, for each hazardous or harmful factor in the workplace. At the same time, the forecast of possible ways of development of a dangerous event under the scheme "Danger" - "Events" - "Consequences" is carried out. The analysis is supplemented with the list of "Existing measures" - organizational and technical measures of health safety engineering and occupational safety at this stage. In conclusion, the working group (WG), based on the principles of the ALARP ("As Low As Reasonably Possible") methodology defines measures to reduce the risks of medium and high levels, to an acceptable level, calculates the "residual risk level", establishes the "Responsible parties" of executors and the "Terms of Work Realization".

\section{Results and discussion}

An example of practical implementation of the methods in question is the "Gas Safety Program". As events, an audit of technological risks was carried out in workplaces with the gasconsuming and gas-producing units, as well as gas pipelines, gas control points and installations. As a result, a list of gas-hazardous jobs and places where gas is available is compiled. This allowed to increase the safety of work in hard-to-reach places, in particular, such as wells of engineering communications. At the same time, normative and technical instructions (based on JSA standards) have been compiled, and changes have been added to the instructions of occupational safety. There are the rules of the mandatory use of personal gas analyzers, provisions for emergency response training, the periodicity of updating personal protective equipment in gas hazardous areas. The realization of the program allowed reducing the number of accidents in the main industry by $30 \%$, in contracting organizations - by $60 \%$. The dynamics of the relative indicators of injuries (injuries ratio) of PJSC "AZOVSTAL" Iron and Steel Works is presented in Figure 2. 
Table 1: The basic matrix of the assessment of occupational risks at PJSC “AZOVSTAL” Iron and Steel Works (Part 1)

\begin{tabular}{|c|c|c|c|c|}
\hline \multicolumn{4}{|c|}{ Risk assessment matrix of occupational safety } & \multirow{3}{*}{$\begin{array}{l}\text { Severity of } \\
\text { conse- } \\
\text { quences, } \\
\text { points/ } \\
\text { points } \\
\end{array}$} \\
\hline \multicolumn{4}{|c|}{ The severity of consequences (actual or potential) } & \\
\hline "Humans" & "Environmental" & "Assets" & "Reputation" & \\
\hline $\begin{array}{l}\text { Death of several } \\
\text { humans } \\
\text { (group deaths) }\end{array}$ & $\begin{array}{l}\text { Critical over-standard impact } \\
\text { on environmental elements. } \\
\text { Exceeding the established } \\
\text { standards more than } 50 \text { times, } \\
\text { or the impact, but the standards } \\
\text { for the source of impact } \\
\text { are not established }\end{array}$ & $\begin{array}{l}\text { Damage, as a result industrial } \\
\text { activity or project activity stops } \\
\text { for a month or more. Financial } \\
\text { costs - more than } \\
100 \text { million UAH }\end{array}$ & $\begin{array}{l}\text { Irreparable damage to reputa- } \\
\text { tion, which leads to significant } \\
\text { financial and other losses. } \\
\text { A long negative PR company } \\
\text { at the national and } \\
\text { international level }\end{array}$ & 5 \\
\hline $\begin{array}{l}\text { Death of one person (death). } \\
\text { Steady full or partial loss of } \\
\text { ability to work of several } \\
\text { humans. Professional diseases } \\
\text { of several people }\end{array}$ & $\begin{array}{l}\text { Significant over-standard } \\
\text { impact on environmental } \\
\text { elements. Exceeding the } \\
\text { established standards } \\
\text { from } 15 \text { to } 50 \text { times }\end{array}$ & $\begin{array}{l}\text { Damage, as a result industrial } \\
\text { activity or project activity } \\
\text { stops for a week or more. } \\
\text { Financial costs - } \\
\text { from } 10 \text { to } 100 \text { million UAH }\end{array}$ & $\begin{array}{l}\text { A hard-to-recover damage to } \\
\text { reputation. Financial and other } \\
\text { loses. Negative PR company } \\
\text { at the national level and } \\
\text { non-long term company } \\
\text { at the international level }\end{array}$ & 4 \\
\hline $\begin{array}{l}\text { Temporary loss of ability } \\
\text { (hospital list) to work } \\
\text { of one person }\end{array}$ & $\begin{array}{l}\text { Low level of over-standard } \\
\text { impact on environmental } \\
\text { elements. Exceeding the } \\
\text { established standards } \\
\text { from } 2 \text { to } 5 \text { times }\end{array}$ & $\begin{array}{l}\text { Damage, as a result industrial } \\
\text { activity or project activity } \\
\text { stops for a one day or several } \\
\text { hours. Financial costs - do not } \\
\text { exceed } 1 \text { million UAH }\end{array}$ & $\begin{array}{l}\text { Short-term repairable damage } \\
\text { to reputation. Negative article } \\
\text { in the local press }\end{array}$ & 2 \\
\hline $\begin{array}{l}\text { Cases without temporary loss } \\
\text { of ability to work. Cases of } \\
\text { first aid, interventions without } \\
\text { hospital list. Cases of tempo- } \\
\text { rary transfer to the easy job }\end{array}$ & $\begin{array}{l}\text { Minimal level of over-standard } \\
\text { impact on environmental } \\
\text { elements. Exceeding } \\
\text { the established standards } \\
\text { more than } 2 \text { times }\end{array}$ & $\begin{array}{l}\text { Damage as a result industrial } \\
\text { activity or project activity do } \\
\text { not stops. Financial costs are } \\
\text { absent or within limit } \\
\text { of current budgets }\end{array}$ & $\begin{array}{l}\text { Insignificant impact on the } \\
\text { reputation. Negative mention } \\
\text { in the local press }\end{array}$ & 1 \\
\hline
\end{tabular}

Table 2: The basic matrix of the assessment of occupational risks at PJSC "AZOVSTAL" Iron and Steel Works (Part 2)

\begin{tabular}{|c|c|c|c|c|c|}
\hline \multirow[b]{2}{*}{$\begin{array}{c}\text { Severity of } \\
\text { consequences, } \\
\text { points/ } \\
\text { points }\end{array}$} & \multicolumn{5}{|c|}{ Probability of consequences, \% } \\
\hline & $\begin{array}{c}\leq 5, \\
\text { Very } \\
\text { low, } \\
\text { most } \\
\text { likely } \\
\text { not } \\
\text { happen }\end{array}$ & $\begin{array}{l}\mathbf{5 - 2 0}, \\
\text { Low, it } \\
\text { is un- } \\
\text { likely to } \\
\text { happen }\end{array}$ & $\begin{array}{l}\text { 21-40, } \\
\text { The } \\
\text { average, } \\
\text { it is } \\
\text { probably } \\
\text { what will } \\
\text { happen. }\end{array}$ & $\begin{array}{c}\mathbf{4 1 - 6 0 ,} \\
\text { High, } \\
\text { most } \\
\text { likely } \\
\text { happen }\end{array}$ & $\begin{array}{l}\geq \mathbf{6 0}, \\
\text { Very } \\
\text { high }\end{array}$ \\
\hline 4 & $5-1$ & $5-2$ & $5-3$ & $5-4$ & $5-5$ \\
\hline 4 & $4-1$ & $4-2$ & $4-3$ & $4-4$ & $4-5$ \\
\hline 3 & $3-1$ & $3-2$ & $3-3$ & $3-4$ & $3-5$ \\
\hline 2 & $2-1$ & $2-2$ & $2-3$ & $2-4$ & $2-5$ \\
\hline $\mathbf{1}$ & $1-1$ & $1-2$ & $1-3$ & $1-4$ & $1-5$ \\
\hline & 1 & 2 & 3 & 4 & 5 \\
\hline
\end{tabular}

Sources of occupational risks are including: thermal electric furnaces (3 units), thermal gas furnaces (3 units), shaft furnace, quench tanks, blowing fan, and mechanical equipment. For example, for dangerous index "blast furnace gas - coke oven gas" the current risk level is "red" or 5-4 in points. The introduction of an automatic burner ignition system, the overhaul of exhaust ventilation from furnaces, the installation of safety valves on all ovens with a response to the drop in gas pressure and the flame attenuation on the burners, and the installation of a stationary gas analyzer is allowed to decrease a residual risk to "yellow" level, 5-2 in points.

The calculation of risk index connected with the identified hazard $[5,7,30]$ is carried out as:

$P=\frac{T[(\Pi+B P)]}{2}$

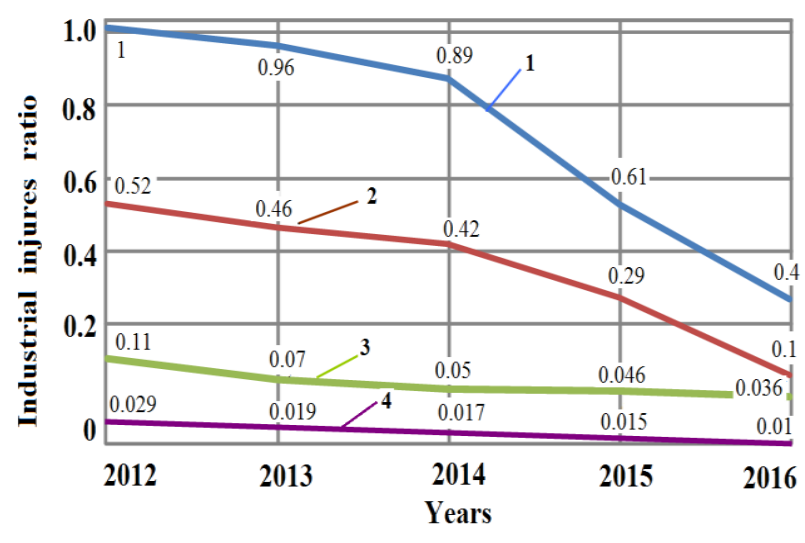

Fig. 2: Dynamics of relative indicators of the level injuries: 1 - Lost Time Injury Frequency Ratio (LTIFR); 2 - Industrial Injures Ratio (IIR); 3 - Fatal-Injury Frequency Ratio (FIFR); 4 - Industrial Death Ratio (IDR)

where $P$-industrial risk index; $T$ - severity of consequences; $\Pi$ - probability of hazard manifestation; $B P$ - frequency of occurrence of a dangerous event.

The frequency of a possible manifestation of a dangerous factor is established on the basis of expert opinions of the working group (WG). Value of BP varies from 1 to 3, which corresponds to the minimum (once a year or less) and to the maximum risk index (daily). For the basic level the values $(P)$ in $2012-2013$ are adopted. A retrospective analysis of the dynamics of the main risk indices in the shop of rail fastenings is presented in the Table 3 .

Researches have shown that technical and organizational measures for health safety engineering and occupational safety for the time from 2012 to 2016 allowed to reduce the level of the total risks index from 121 to 74 points (Figure 3). 
Table 3: The calculation of the risk indices in rail fastenings shop

\begin{tabular}{lccccc}
\hline & \multicolumn{5}{c}{ Risk index, P, points } \\
\cline { 2 - 6 } Risk factor & $\mathbf{2 0 1 2}$ & $\mathbf{2 0 1 3}$ & $\mathbf{2 0 1 4}$ & $\mathbf{2 0 1 5}$ & $\mathbf{2 0 1 6}$ \\
\hline Blast-furnace gas & 18 & 18 & 8 & 8 & 8 \\
Open fire & 6 & 6 & 6 & 3 & 3 \\
Infrared radiation & 12 & 12 & 11 & 11 & 11 \\
Asbestos, Cement dust, & 9 & 9 & 9 & 3 & 3 \\
Sodium salt & 9 & 9 & 6 & 6 & 6 \\
Pendant equipment & 4 & 4 & 4 & 4 & 4 \\
Hot surfaces with $\mathrm{t} \geq 150^{\circ} \mathrm{C}$ & 13 & 13 & 10 & 10 & 10 \\
Hot liquids, oil with $\mathrm{t} \geq 900^{\circ} \mathrm{C}$ & 6 & 6 & 5 & 5 & 5 \\
Loading equipment & 12 & 12 & 12 & 9 & 9 \\
Heat stress & 20 & 20 & 8 & 8 & 8 \\
Gas furnace No.2 & 10 & 10 & 10 & 6 & 6 \\
Exhaust ventilation & & & & & \\
from furnaces & 2 & 2 & 1 & 1 & 1 \\
Condition of equipment & 121 & 121 & 90 & 74 & 74 \\
insulation & & & & &
\end{tabular}

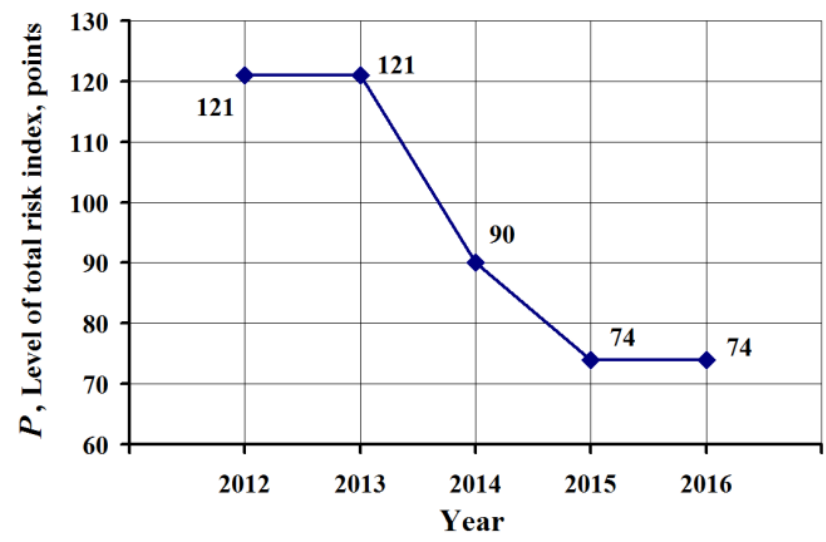

Fig. 3: Dynamics of the total risk index at the rail fastenings shop of PJSC "AZOVSTAL” Iron and Steel Works

Thus, the level of total risk index is reduced by $61 \%$. The residual total risk index is characterized as "substantial and requiring the necessary improvements".

\section{Conclusion}

It is shown that the introduction of international methods of risks prevention in accordance to the standards for the audit of production risks such as HAZID, HAZOP, JSA, etc. is an effective way to increase the potency of the management system in the field of health safety engineering and occupational safety. A matrix of risk assessment in the field of health safety engineering, occupational safety and environmental engineering was developed and tested using the example of the PJSC "AZOVSTAL" Iron and Steel Works. The new methodology allows assessing of occupational safety risks at the current World level, using international indices. The efficiency of the new risk prevention methodology is confirmed by a 30-60\% reduction in injuries ratios that approved in the European Union. Technical and organizational measures to reduce of production risks in the energetic sector of the enterprise's rail fasteners shop allowed to decrease the level of residual total risk by $61 \%$ to an "acceptable level" (74 points).

\section{References}

[1] Abolfazl Ghahramani, and Heikki Summala, "A study of the effect of OHSAS 18001 on the occupational injury rate in Iran", International Journal of Injury Control and Safety Promotion, (2015), pp. 1-6, http://dx.doi.org/10.1080/17457300.2015.1088038.

[2] Ligade, A.S., and Thalange, S.B., "Occupational health and safety management system (OHSMS) model for construction industry",
IJRET: International Journal of Research in Engineering and Technology, IC-RICE Conference Issue, (2013), pp. 395-399.

[3] Tine Herreborg Jørgensen, and Ole Busck, "Occupational health and safety regulation and management systems: experiences from Denmark", Division of Technology, Environment and Society, Department of Development and Planning, Aalborg University, Working Paper 8, (2004), pp. 1-11.

[4] Jesús Álvarez-Santos, José-Á. Miguel-Dávila, Liliana Herrera, and Mariano Nieto, "Safety Management System in TQM environments", Safety Science, Vol. 101, (2018), pp. 135-143, http://dx.doi.org/10.1016/j.ssci.2017.08.019.

[5] Berkhout, P.H.G., and Damen, M. "Estimating individual occupational risk using registration data", Safety Science, Vol. 82, (2016), pp. 95-102, http://dx.doi.org/10.1016/j.ssci.2015.08.013.

[6] Kontogiannis, T., Leva, M.C., and Balfe, N., "Total Safety Management: Principles, processes and methods", Safety Science, Vol. 100, Part B, (2017), pp. 128-142, http://dx.doi.org/10.1016/j.ssci.2016.09.015.

[7] Adel Badri, André Gbodossou, and Sylvie Nadeau, "Occupational health and safety risks: Towards the integration into project management”, Safety Science, Vol. 50, Issue 2, (2012), pp. 190-198, http://dx.doi.org/10.1016/j.ssci.2011.08.008.

[8] Beatriz Fernández-Muñiz, José Manuel Montes-Peón, and Camilo José Vázquez-Ordás, "The role of safety leadership and working conditions in safety performance in process industries", Journal of Loss Prevention in the Process Industries, Vol. 50, Part B, (2017), pp. 403-415, http://dx.doi.org/10.1016/j.jlp.2017.11.001.

[9] Fadwa Eljack, and Monzure-Khoda Kazi, "Process safety and abnormal situation management", Current Opinion in Chemical Engineering, Vol. 14, (2016), pp. 35-41, http://dx.doi.org/10.1016/j.coche.2016.07.004.

[10] Vinodkumar, M.N., and Bhasi M., "Safety management practices and safety behaviour: Assessing the mediating role of safety knowledge and motivation", Accident Analysis \& Prevention, Vol. 42, Issue 6, (2010), pp. 2082-2093, http://dx.doi.org/10.1016/j.aap.2010.06.021.

[11] Vinodkumar, M.N., and Bhasi M., "A study on the impact of management system certification on safety management", Safety Science, Vol. 49, Issue 3, (2011), pp. 498-507, http://dx.doi.org/10.1016/j.ssci.2010.11.009.

[12] Chinniah, Y., "Analysis and prevention of serious and fatal accidents related to moving parts of machinery", Safety Science, Vol. 75, (2015), pp. 163-173, http://dx.doi.org/10.1016/j.ssci.2015.02.004.

[13] Lutsenko, I., Fomovskaya, E., Oksanych, I., Koval, S., and Serdiuk, O., "Development of a verification method of estimated indicators for their use as an optimization criterion", Eastern-European Journal of Enterprise Technologies, Vol. 2, No. 4 (86), (2017), pp. 17-23, http://dx.doi.org/10.15587/1729-4061.2017.95914.

[14] Bogoliubov, V.M., Nagorniuk, O.M., and Sobczyk, W., "Providing environmental training in the context of Ukraine's transition to sustainable development", Annals of Agrarian Science, Vol. 14, Issue 4, (2016), pp. 292-294, http://dx.doi.org/10.1016/j.aasci.2016.09.003.

[15] Manual for Occupational Safety in PJSC "ArcelorMittal Kryvyi Rih", Krivoi Roh, (2014), 74 p. (in rus.), available online: https://ukraine.arcelormittal.com/images/pdf/rukovodstvo_hs_2014.pdf.

[16] Report on occupational safety of PJSC "ArcelorMittal Kryvyi Rih" for 2011, Krivoi Roh, (2011), 18 p. (in rus.), available online: https://ukraine.arcelormittal.com/images/pdf/H\&S_Report_2011.pdf.

[17] Kukhar, V., Balalayeva, E., and Nesterov, O., "Calculation Method and Simulation of Work of the Ring Elastic Compensator for SheetForming", MATEC Web of Conferences, Vol. 129, (2017), 01041, http://dx.doi.org/10.1051/matecconf/201712901041.

[18] Elena Balalayeva, Viktor Artiukh, Volodymyr Kukhar, Olga Tuzenko, Glazko Vladyslav, Andrii Prysiazhnyi, and Kankhva Vadim, "Researching of the Stress-Strain State of the Open-Type Press Frame Using of Elastic Compensator of Errors of "Press-Die" System", Advances in Intelligent Systems and Computing, Vol. 692, pp. 220-235, http://dx.doi.org/10.1007/978-3-319-70987-1_24.

[19] Bogdan Pawłowski, Piotr Bała, Janusz Krawczyk, Milena Stępień, and Tomasz Śleboda, "Failure analysis of shock absorber tubes", Engineering Failure Analysis, Vol. 82, (2017), pp. 533-539, http://dx.doi.org/10.1016/j.engfailanal.2017.04.009.

[20] Kukhar, V.V., and Vasylevskyi, O.V. "Experimental research of distribution of strains and stresses in work-piece at different modes of stretch-forging with rotation in combined dies", Metallurgical and Mining Industry, No. 3, (2014), pp.71-78, available online: http://www.metaljournal.com.ua/assets/ Archive/en/MMI3/14.pdf. 
[21] Grushko, A.V., Kukhar, V.V., and Slobodyanyuk, Yu.O., "Phenomenological Model of Low-Carbon Steels Hardening during Multistage Drawing", Solid State Phenomena, Vol. 265, (2017), pp. 114-123, http://dx.doi.org/10.4028/www.scientific.net/SSP.265.114.

[22] Volodymyr Kukhar, Andrii Prysiazhnyi, Elena Balalayeva, and Oleksandr Anishchenko, "Designing of induction heaters for the edges of pre-rolled wide ultrafine sheets and strips correlated with the chilling end-effect", Modern Electrical and Energy System (MEES'2017), IEEE, Kremenchuk, Ukraine, (2017), pp. 404-407, http://dx.doi.org/10.1109/MEES.2017.8248945

[23] Volodymyr Kukhar, Victor Artiukh, Andrey Butyrin, and Andrii Prysiazhnyi, "Stress-Strain State and Plasticity Reserve Depletion on the Lateral Surface of Workpiece at Various Contact Conditions during Upsetting", Advances in Intelligent Systems and Computing, Vol. 692, (2018), pp. 201-211, http://dx.doi.org/10.1007/978-3319-70987-1_22.

[24] Albert Sesé, Alfonso L. Palmer, Berta Cajal, Juan J. Montaño, Rafael Jiménez, Noelia Llorens, "Occupational safety and health in Spain”, Journal of Safety Research, Vol. 33, Issue 4, (2002), pp. 511-525, http://dx.doi.org/10.1016/S0022-4375(02)00054-3.

[25] Danuta Koradecka, and Helena Dryzek, "Occupational safety and health in Poland", Journal of Safety Research, Vol. 32, Issue 2, (2001), pp. 187-208, http://dx.doi.org/10.1016/S00224375(01)00044-5.

[26] Arquillos, A.L., Romero, J.C.R., Gibb, A., "Analysis of construction accidents in Spain, 2003-2008", Journal of Safety Research, Vol. 43, (2012),

pp. 381-388,
[27] Emma Maano Nghitanwa, and Lindiwe I Zungu, "Occupational health and safety provision awareness among construction workers on the construction industry of Windhoek, Namibia", International Journal of Health, Vol. 5, No. 1, (2017), pp.60-63, http://dx.doi.org/10.14419/ijh.v5i1.7294.

[28] Zeng, S.X., Tam, V.W.Y., and Tam, C. "Towards occupational health and safety systems in the construction industry of China", Safety Science, Vol. 46 (8), (2008), pp. 1155-1168 https://dx.doi.org/10.1016/j.ssci.2007.08.005.

[29] Helena Ranängen, and Thomas Zobel, "Exploring the path from management systems to stakeholder management in the Swedish mining industry", Journal of Cleaner Production, Vol. 84, (2014), pp. 128-141, https://dx.doi.org/10.1016/j.jclepro.2014.04.025.

[30] Kudryavtsev, Sergey S., Yemelin, Pavel V., and Yemelina Natalya K., "The Development of a Risk Management System in the Field of Industrial Safety in the Republic of Kazakhstan", Safety and Health Work, (2017), http://dx.doi.org/10.1016/j.shaw.2017.06.003.

[31] Nilgun Ulutasdemir, Metin Cirpan, Ebru Ozturk Copur, and Ferdi Tanir, "Occupational Risk of Health Professionals in Turkey a an Emerging Economy", Annals of Global Health, Vol. 81, No. 4, (2015), pp. 522-529, http://dx.doi.org/10.1016/j.aogh.2015.08.019.

[32] Diana Maria Ceballos, and Zhao Dong, "The formal electronic recycling industry: Challenges and opportunities in occupational and environmental health research", Environment International, Vol. 95, (2016), pp. 157-166, https://dx.doi.org/10.1016/j.envint.2016.07.010. 